\title{
Pseudotorellia Florin from the Upper Jurassic-Lower Cretaceous of the Bureya Basin, Russian Far East
}

\author{
N. V. Nosova ${ }^{a, *}$, E. I. Kostina ${ }^{b}$, and E. V. Bugdaeva ${ }^{c}$ \\ ${ }^{a}$ Komarov Botanical Institute, Russian Academy of Sciences, St. Petersburg, 197376 Russia \\ ${ }^{b}$ Geological Institute, Russian Academy of Sciences, Moscow, 119017 Russia \\ ${ }^{c}$ Federal Scientific Center of the East Asia Terrestrial Biodiversity, Far Eastern Branch, Russian Academy of Sciences, \\ Vladivostok, 690022 Russia \\ *e-mail: natanosova@gmail.com
}

Received December 4, 2020; revised December 25, 2020; accepted December 31, 2020

\begin{abstract}
The leaves of the genus Pseudotorellia from the Upper Jurassic-Lower Cretaceous of the Bureya Basin (Russian Far East) have been revised. The similarity of Pseudotorellia angustifolia Doludenko and $P$. longifolia Doludenko in the morphology and epidermal characters suggests that $P$. longifolia is a synonym of $P$. angustifolia. Leaves of this genus from the Bureya Basin previously assigned to P. ensiformis (Heer) Doludenko according to both morphological and epidermal characters are described as a new species $P$. doludenkoae sp. nov., since the type specimens of $P$. ensiformis from the Irkutsk Basin do not have preserved cuticles and their leaf epidermal characters are unknown. The epidermal characters of leaves described previously as Pseudotorellia pulchella and P. crassifolia have been studied for the first time. Since these species have similar morphological and epidermal characters, they are described as $P$. crassifolia, and its emended diagnosis is provided. The well-defined epidermal characters of Pseudotorellia allow us to reliably assign even cuticle fragments and dispersed cuticles to a particular species. This indicates a large stratigraphic potential of the Pseudotorellia species for the intrabasin and interregional stratigraphy of continental deposits, especially when studying the core material and coals, where the preservation of plant remains usually does not allow describing their morphology. The revision of all known occurrences of Pseudotorellia angustifolia makes it possible to discuss the place and time of the first appearance of this species and its subsequent distribution in space and time. Apparently, this species appeared in the Early Jurassic of Eastern Siberia (Kansk Basin). In the Middle Jurassic, its range expanded both to the northwest (Tomsk oblast and Yamal-Nenets Autonomous Okrug), where this species was preserved until the Late Jurassic, and to the east (Irkutsk oblast, Khabarovsk krai (Bureya Basin)), where it survived until the Early Cretaceous.
\end{abstract}

Keywords: Pseudotorellia, Upper Jurassic, Lower Cretaceous, Bureya Basin

DOI: $10.1134 / \mathrm{S} 0869593821040031$

\section{INTRODUCTION}

The genus Pseudotorellia Florin was distinguished for linear leaves from the Lower Cretaceous deposits of Spitsbergen, which are characterized by several parallel veins and a specific structure of the epidermis (Florin, 1936). The genus diagnosis was repeatedly clarified (Bose and Manum, 1990; Kiritchkova and Nosova, 2009; Watson, 1969). The Pseudotorellia leaves are linear to lanceolate or obovate. The apex is obtuse, rounded or pointed, whole or finely toothed. There are two veins at the leaf base: dichotomizing at the base and parallel-arranged in the mid-leaf. Most Pseudotorellia species are characterized by the presence of stomata only on the lower surface of the leaf (hypostomaty). The only species with amphistomatic leaves, P. amphistomatica Nosova et Golovneva, was described from the Albian of Western Siberia (Golovneva and Nosova, 2012). Stomata are oriented longitu- dinally, less often obliquely. They can be distributed randomly on the entire surface of a leaf or form discontinuous rows and bands. The guard cells of the stomata are sunken, wing-like, often with long polar appendages.

Having studied ginkgoaleans and czekanowskialeans from the Mesozoic deposits of the Bureya Basin, Krassilov (1972) described short shoots with attached Pseudotorellia leaves together with female reproductive structures, which he allocated to the genus Umaltolepis Krassilov. Based on the similarity of epidermal features, he assigned Pseudotorellia and Umaltolepis to the new family Pseudotorelliaceae within the Ginkgoales (Krassilov, 1972). Stanislavsky (1973), followed by Zhou (1991), used the family name Umaltolepidaceae for plants PseudotorelliaUmaltolepis. Later, the associated finds of Pseudotorellia and Umaltolepis were described from the Lower 
Jurassic of Northern Iran (Schweitzer and Kirchner, 1995), the Middle Jurassic of Central China (Dong et al., 2019) and Uzbekistan (Nosova, 2020), and the Lower Cretaceous of Northeastern China (Chen et al., 1988; Wang, 1984) and Central Mongolia (Herrera et al., 2017).

Having studied the reproductive structures from the Aptian-Albian Tevshiin Govi Formation (Mongolia) in detail and revised the type material from the Jurassic of the Bureya Basin, Herrera et al. (2017) concluded that Umaltolepis differs significantly from the female reproductive structures of ginkgoaleans and is significantly similar to the fructifications of Vladimaria Gordenko (2010) from the Middle Jurassic of European Russia. These authors assigned Umaltolepis to the order Vladimariales proposed by Gordenko (2010). In the article (Dong et al., 2019), devoted to Umaltolepis from the Middle Jurassic of Central China, the family Umaltolepidaceae assigned to the Ginkgoales sensu lato. However, only some Pseudotorellia species can be assigned with confidence to the family Umaltolepidaceae. For example, in the article devoted to the description of the female reproductive structures of Umkomasia Thomas from the Lower Cretaceous of Mongolia (Shi et al., 2019), the authors presented the reconstruction of a plant with the leaves of Pseudotorellia palustris Shi, Herrera, Herendeen, Leslie, Ichinnorov, Takahashi et Crane and the female reproductive structures of Umkomasia mongolica Shi, Leslie, Herendeen, Herrera, Ichinnorov, Takahashi, Knopf et Crane and assigned the Pseudotorellia leaves to the family Umkomasiaceae in the Umkomasiales.

Originally, Pseudotorellia leaf remains from the Upper Jurassic-Lower Cretaceous of the Bureya Basin (Khabarovsk krai, Russian Far East) were studied by M.P. Doludenko (Vakhrameev and Doludenko, 1961). As a result, five species were recognized: Pseudotorellia angustifolia Doludenko, $P$. ensiformis (Heer) Doludenko, P. longifolia Doludenko, P. pulchella (Heer) Vassilevskaja, and $P$. crassifolia (Prynada) Doludenko; the last two species were distinguished on the basis of the morphological features.

Heer (1876) described isolated lanceolate leaves with missing cuticle from the Jurassic Ust'-Baley locality (Irkutsk Basin, Eastern Siberia) as Podozamites ensiformis. Doludenko proposed the combination Pseudotorellia ensiformis based on the studied morphology and epidermal structure of leaves from the Bureya Basin (Vakhrameev and Doludenko, 1961), including Podozamites ensiformis in the given taxon. Later, however, Doludenko and Rasskazova noted that the identification of leaves from the Bureya Basin with those from the Irkutsk Basin was incorrect since the epidermal features of the latter are unknown (Doludenko and Rasskazova, 1972, p. 21). These authors proposed to attribute leaves with unknown epidermal characters but having the same morphology as the lectotype from the Ust'-Baley to
Pseudotorellia ensiformis. Krassilov (1972) gave the new description and emended diagnosis of $P$. angustifolia, considering P. ensiformis as a synonym of P. angustifolia.

The authors of the present paper have revised specimens with Pseudotorellia leaves from the collections of V.A. Vakhrameev and V.A. Krassilov and concluded that $P$. angustifolia and $P$. ensiformis described by Doludenko differ significantly in both morphological and epidermal characters. Since the epidermal characters of the type specimens of $P$. ensiformis from Ust'-Baley are unknown, a new species $P$. doludenkoae sp. nov. is distinguished for leaves from the Bureya Basin.

The detailed study and comparison the leaf epidermal features of Pseudotorellia angustifolia with those of $P$. longifolia from the Bureya Basin have revealed no significant differences between these species. Therefore, they are united into one species, and the species name $P$. longifolia is taken as a synonym of $P$. angustifolia (see description and remarks below).

The combination Pseudotorellia crassifolia was proposed by Doludenko only on the basis of the morphological features (Vakhrameev and Doludenko, 1961). The present paper presents an emended diagnosis and an extended description of this species based on the study of the leaf epidermal features from the holotype.

Another species from the Bureya Basin, Pseudotorellia pulchella, was also described only on the basis of the morphological characters (Vakhrameev and Doludenko, 1961). Originally, leaves with such features were described from the Lower Cretaceous of Spitsbergen as Podozamites pulchellus Heer, 1876. On the basis of the material from the Lower Cretaceous of the Lena Basin (Eastern Siberia), Vasilevskaya (1959) proposed the combination Pseudotorellia pulchella. The epidermal structure of leaves from both Spitsbergen and the Lena Basin is unknown. Having studied the epidermal structure of the leaves of $P$. pulchella from the Bureya Basin, the authors of the present paper have concluded that their morphological and epidermal characters are similar to those of $P$. crassifolia. Since, unlike $P$. pulchella, the type material of $P$. crassifolia comes from the Bureya Basin, the Bureya leaves described as $P$. pulchella are included in $P$. crassifolia (see description below). It is proposed to assign leaves the epidermal structure of which is unknown and the morphological features are similar to those of the type specimens from Spitsbergen to $P$. pulchella.

We support the opinion of Herrera with co-authors (Herrera et al., 2017) and assign the Pseudotorellia leaves from the Bureya Basin to the order Vladimariales since they were found together with Umaltolepis fructifications (Krassilov, 1972). 


\section{MATERIALS AND METHODS}

We have revised specimens with leaf remains of Pseudotorellia collected in 1958 by V.A. Vakhrameev and E.L. Lebedev with the participation of M.L. Edemsky in the Bureya Basin (Khabarovsk krai, Russian Far East). The collection (no. 3318) is stored in the Geological Institute of the Russian Academy of Sciences (GIN RAS, Moscow).

The studied material was collected on the right bank of the Bureya River, in the Kataevskaya channel area, downstream of the Umalta River mouth, and on the mine no. 3 dumps near the settlement of Chegdomyn (Fig. 1).

Plant remains found in the coastal deposits along the Kataevskaya channel were described by Doludenko as Pseudotorellia angustifolia (GIN RAS, spec. nos. 3318/120-26 and 3318/120-27) and P. ensiformis (GIN RAS, spec. nos. 3318/118-1, 3318/118-2, and $3318 / 120-25)$. Leaf remains from the coastal outcrops along the Bureya River right bank, downstream of the Umalta River mouth, were described by Doludenko as P. ensiformis (GIN RAS, spec. nos. 3318/52-3, 3318/52-4, 3318/54-9, and 3318/57-6), P. pulchella (GIN RAS, spec. no. 3318/57-22), and $P$. crassifolia (GIN RAS, spec. no. 3318/58-3). Leaf remains from the dumps of mine no. 3 in the environs of Chegdomyn were described by Doludenko as P. longifolia (GIN RAS, spec. no. 3318/9-38). Unfortunately, we were not able to find some specimens from the collection GIN RAS no. 3318 (spec. nos. 3318/52-3, 3318/54-9, 3318/118-1, $3318 / 118-2$, and 3318/120-25), but we have at our disposal slides with leaf cuticles made by Doludenko with the same numbers.

We have also studied specimens with the Pseudotorellia leaves from the collection collected by V.A. Krassilov at the same locality on the right bank of the Bureya River, downstream of the Umalta River mouth. The collection no. 515 is stored at the Federal Scientific Center of the East Asia Terrestrial Biodiversity of the Far Eastern Branch of the Russian Academy of Sciences, Vladivostok (FSC EATB FEB RAS) (spec. nos. 515/272 and 515/284).

Fossil cuticles were prepared according to the standard maceration method.

The cuticles were examined using a Carl Zeiss Axio Scope A1 light microscope equipped with a Lomo Microsystems MC-6.3 digital camera and a JSM-6390 LA scanning electron microscope (SEM) at the Botanical Institute of the Russian Academy of Sciences (BIN RAS), an Axiostar plus light microscope equipped with a Canon A640 digital camera at the Geological Institute of the Russian Academy of Sciences (GIN RAS, Moscow), a Carl Zeiss Axioscop 40 light microscope equipped with a Axiocam HRc digital camera, and a Carl Zeiss EVO 40 scanning electron microscope at FSC EATB FEB RAS (Vladivostok).

Slides with leaf cuticles are stored at the Laboratory of Paleofloristics of the Geological Institute of Rus- sian Academy of Sciences (Moscow), the Laboratory of Paleobotany of the Botanical Institute of the Russian Academy of Sciences (St. Petersburg), and the Laboratory of Paleobotany of the FSC EATB FEB RAS (Vladivostok).

\section{STRATIGRAPHY OF THE JURASSIC AND LOWER CRETACEOUS PLANT-BEARING DEPOSITS OF THE BUREYA BASIN}

Vakhrameev attributed the plant-bearing beds with remains of the Pseudotorellia leaves from the right bank of the Bureya River, downstream from the Umalta River mouth, and deposits cropping out along the Kataevskaya channel (Azanov stratum) to the Talyndzhan Formation and leaf remains from the outskirts of the settlement of Chegdomyn firstly to the Soloni (upper) Subformation of the Urgal Formation (Vakhrameev and Doludenko, 1961) and later to the upper part of the Talyndzhan Formation (Vakhrameev and Lebedev, 1967, p. 127).

Even earlier, Davydova and Goldshtein (1949) suggested subdividing the Urgal Formation into two formations: Dublikan and Soloni. However, Vakhrameev and Doludenko (1961) used the name "Urgal Formation", dividing it into two subformations: Dublikan and Soloni. Later, these subformations were promoted to the rank of formations (Resheniya..., 1994).

Vakhrameev and Lebedev dated the fossil plants from the Talyndzhan and Dublikan formations as the Late Jurassic, assuming that they are notably different from those from the Soloni Formation, lying at the base of the Lower Cretaceous (Lebedev and Paraketsov, 1975; Vakhrameev and Lebedev, 1967).

Having studied all the known sections of the Bureya Basin in detail, Krassilov (1973) noticed that the plant assemblage from deposits exposed along the Kataevskaya channel (Azanov stratum) is similar to that from the Dublikan Formation. In addition, he attributed plant-bearing deposits on the left bank of the Urgal River and deposits in the outskirts of Chegdomyn to the same formation. The plant assemblage from the Talyndzhan Formation was dated as the Callovian-Oxfordian; the one from the Dublikan Formation was dated as the Tithonian-Berriasian.

In the last years, the large- and medium-scale geological mapping of the Bureya Basin was completed, and geological maps of the new generation were compiled (Anoikin, 2003; Gosudarstvennaya..., 2009). The ages of the formations and strata are indicated following the resolutions adopted at the IV Interdepartmental Regional Stratigraphic Meeting on the Precambrian and Phanerozoic South of the Far East and Eastern Transbaikalia (Resheniya..., 1994).

Based on the lithology and structural and textural features of the deposits, three units are distinguished in the Talyndzhan Formation. The two bottom units are combined into the lower subformation, and the 

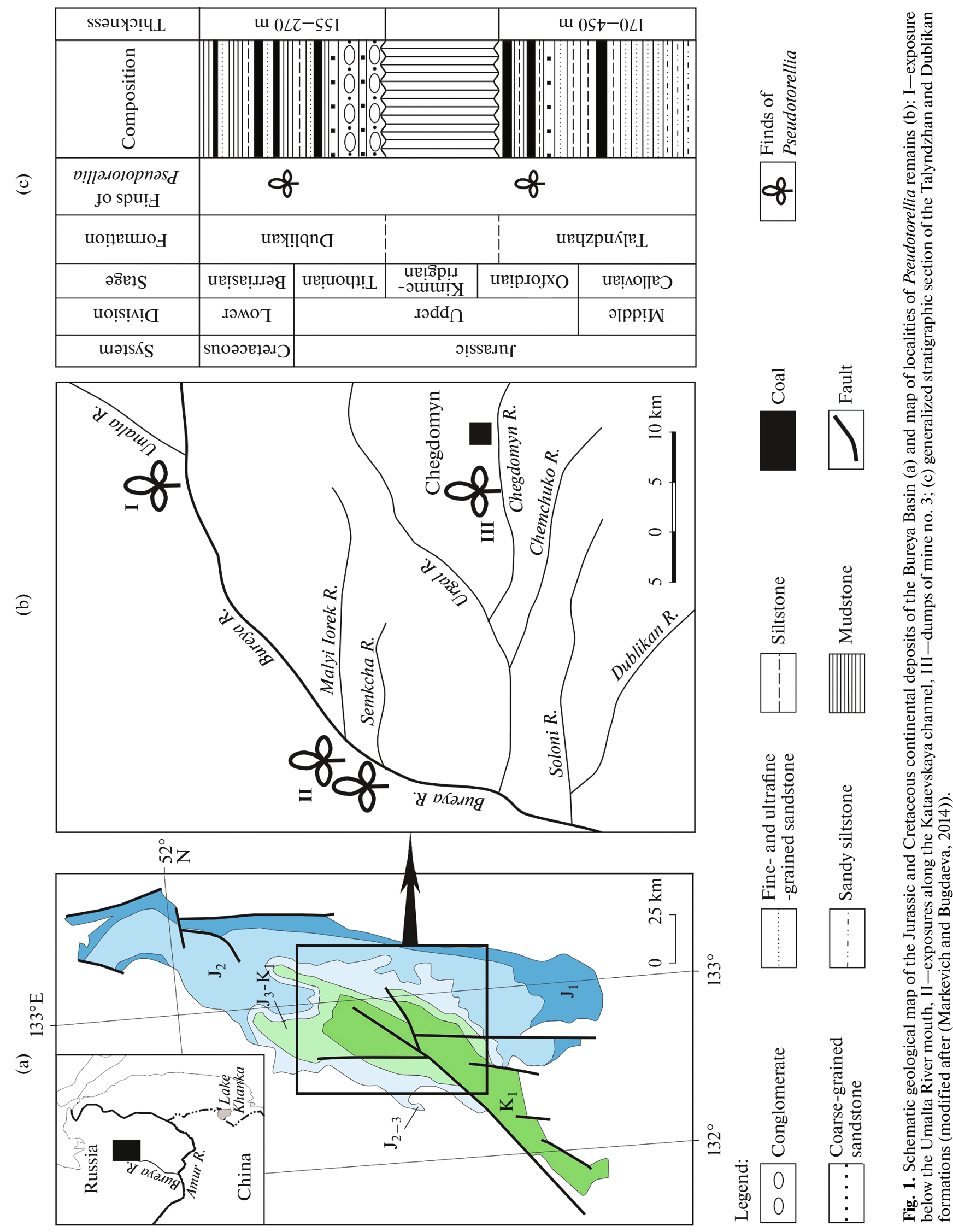
upper one corresponds to the upper subformation. The age of the lower subformation was determined as the Callovian, and the age of the upper subformation was determined as the Oxfordian (Resheniya..., 1994). Beds with remains of Pseudotorellia leaves belong to the upper subformation of the Talyndzhan Formation.

The Talyndzhan Formation is overlain with an erosional unconformity by the Dublikan Formation. In (Resheniya..., 1994), the Dublikan Formation is dated as the Volgian. On the basis of the palynological data, Markevich (1995; Markevich and Bugdaeva, 2009) dated the Dublikan Formation as the Berriasian. In the explanatory note to the $1: 1000000$ State Geological Map of the Russian Federation (sheet M-52), the age of the Dublikan Formation plant assemblage is interpreted as "the top of the Upper Jurassic (Volgian or Tithonian Stage), although the Lower Cretaceous (Berriasian) is not excluded" (Petruk et al., 2012, p. 34).

The authors of the present paper follow a more substantiated point of view of Krassilov (1973) and take the age of the Talyndzhan Formation as the Callovian-Oxfordian and the age of the Dublikan Formation as the Tithonian-Berriasian (Fig. 1).

TAXONOMIC DESCRIPTION OF PSEUDOTORELLIA SPECIES

\section{L A S S GINKGOOPSIDA}

\section{O R D E R VLADIMARIALES GORDENKO, 2010}

FAMILY UMALTOLEPIDACEAE STANISLAVSKY, 1973, EMEND. Z. ZHOU, 1991

Genus Pseudotorellia Florin, 1936

Pseudotorellia angustifolia Doludenko, 1961, emend. Nosova

Plate I, figs. 1-4; Plate II

Pseudotorellia angustifolia: Vakhrameev and Doludenko, 1961, p. 114, Plate LVII, figs. 1-9.

Pseudotorellia angustifolia: Krassilov, 1972, p. 58, pro parte, Plate XX, figs. 1-11; Plate XXI, figs. 1, 2, 4, 6-13; Figs. 9, 10a10i, 10s, 10t.

Pseudotorellia angustifolia: Kostina, 2004, p. 59, Plate XXXIX, figs. $1-9$.

Pseudotorellia angustifolia: Kiritchkova et al., 2005, p. 107, Plate LI, figs. 1-8; Plate LII, figs. 1-5.

Pseudotorellia angustifolia: Kiritchkova et al., 2020, p. 110, Plate CXV, figs. 1-8.

Pseudotorellia longifolia Doludenko: Vakhrameev and Doludenko, 1961, p. 115, Plate LVIII, figs. 1-8.

Pseudotorellia longifolia: Doludenko and Rasskazova, 1972, p. 22, Plate XXX, figs. 1-7; Plate XXXI, figs. 1-4.
Pseudotorellia angaranica Kiritchkova et Nosova: Kiritchkova et al., 2020, p. 108, Plate CXVII, figs. 7, 8; Plate CXVIII, figs. 2a, 7-10; Plate CXXI, figs. 1a, 2-11.

H ol o t y p e. GIN RAS, no. 3318/120-27b; Russian Far East, the right bank of the Bureya River, Kataevskaya channel; Dublikan Formation, Tithonian-Berriasian; Vakhrameev and Doludenko, 1961, p. 114, Pl. LVII, fig. 6; designated here, Plate I, figs. $2 b, 3$.

E m e n d e d d i ag n o s is. Leaves linear, narrow, and long, apex rounded or acute. Veins $3-8$ per widest part. Leaves hypostomatic. Ordinary epidermal cells of upper and lower epidermis are elongated and rectangular, without cuticular ridges or papillae; anticlinal cell walls straight. Stomata sparse, arranged in bands, rarely irregularly scattered in the lower epidermis. Subsidiary cells without papillae, rarely with small proximal papillae.

Description. Leaves are linear (Plate I, figs. 1-4), 1.5-5 mm wide in the middle part, 60$80 \mathrm{~mm}$ and more long. Apices are obtuse or rounded. There are 3-8 veins in the middle part of a leaf (810 veins per $5 \mathrm{~mm}$ of a leaf blade width). Resin ducts, $65-116 \mu \mathrm{m}$ wide, are arranged between the veins; the maximum resin length is $1000 \mu \mathrm{m}$ (Plate II, fig. 2).

Leaves the hypostomatic (Plate II, fig. 3). The upper epidermis consists of elongated narrow tetragonal cells $(8-38 \times 60-130 \mu \mathrm{m}$, width/length $=1 / 3-1 / 13$, rarely $1 / 5-1 / 7$ ), often forming rows (Plate II, figs. $3-5$ ). Corners of the epidermal cells are acute, rarely rounded; the anticlinal cell walls are straight; the periclinal walls are smooth.

The lower epidermis consists of alternating stomatal $(139-383 \mu \mathrm{m})$ and nonstomatal $(157-306 \mu \mathrm{m})$ bands (Plate II, figs. 3, 6, 9). The stomatal bands in some leaf fragments are indistinctly defined, sometimes merging. In some cases, the stomata do not form bands (Plate II, fig. 6). The ordinary cells of stomatal and nonstomatal bands are the same in shape and size as the cells of the upper epidermis, with straight anticlinal and smooth periclinal walls. There are $1-3$ stomata per width of the stomatal band in narrow leaves (Plate II, figs. 1, 3) and up to 4 stomata per width of the stomatal band in broad leaves (Plate II, fig. 9). Stomata in the stomatal bands are distributed quite rarely, not forming rows, and are oriented longitudinally. Stomatal complexes are monocyclic, often elongated. Most subsidiary cells of the stomata lack papillae; in

Plate I. Leaves of Pseudotorellia. Scale bars $10 \mathrm{~mm}$. (1-4) Pseudotorellia angustifolia Doludenko, Dublikan Formation, Tithonian-Berriasian: (1-3) the right bank of the Bureya River, Kataevskaya channel: (1) accumulation of leaves, spec. no. 3318/120-26; (2) accumulation of leaves: (2a) spec. no. 3318/120-27a, (2b) spec. no. 3318/120-27b; (3) leaf magnified from fig. 2, spec. no. 3318/120-27b (holotype); (4) Chegdomyn settlement (mine no. 3), accumulation of leaves, spec. no. 3318/9-38; (5, 6, 8) Pseudotorellia doludenkoae Nosova, Kostina et Bugdaeva, the right bank of the Bureya River, downstream of the Umalta River mouth; the upper subformation of the Talyndzhan Formation, Oxfordian: (5a-5d) four leaves, spec. no. 515/284; (6) leaf magnified from fig. 5a, spec. no. 515/284a (holotype); (8) accumulation of leaves, spec. no. 515/272; (7, 9, 10) Pseudotorellia crassifolia Doludenko, the right bank of the Bureya River, downstream of the Umalta River mouth; the upper subformation of the Talyndzhan Formation, Oxfordian: (7a, 7b) leaves, spec. no. 3318/58-3 (7a-holotype); (9) magnifed apices of leaves from fig. 10, spec. no. 3318/57-22; (10) accumulation of leaves, spec. no. 3318/57-22. 


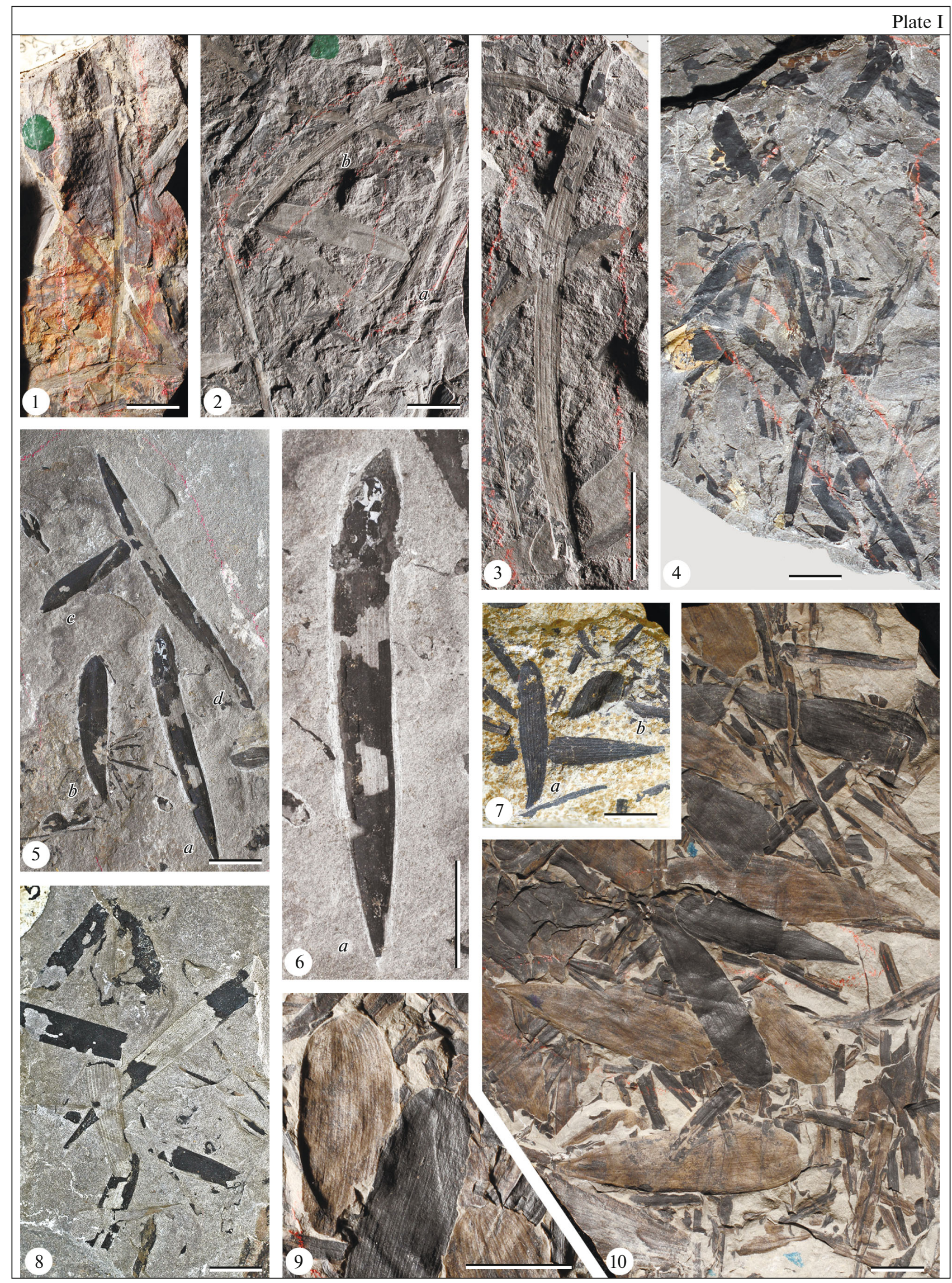

STRATIGRAPHY AND GEOLOGICAL CORRELATION Vol. $29 \quad$ No. $4 \quad 2021$ 
rare cases, they bear a small proximal papillae (Plate II, figs. 10, 11). Appendages of the guard cells are observed in the polar parts of stomata (Plate II, fig. 13). Stomata with these appendages are $70-76 \mu \mathrm{m}$ long; the guard cells without appendages are 34-65 $\mu \mathrm{m}$ long and $10-$ $13 \mu \mathrm{m}$ wide. After the maceration, the outer walls, sometimes the apertural and epidermal walls, and rarely the inner walls of the guard cells are preserved (Plate II, figs. $8,12,13)$. The epidermal walls of the guard cells are often bent toward the aperture and are visible under an light microscope as two narrow lateral crescents (Plate II, figs. 1, 7, 10, 13).

Comparison and remarks. According to Doludenko's descriptions (Vakhrameev and Doludenko, 1961), $P$. longifolia leaves are somewhat wider $(3-5 \mathrm{~mm})$ than those of $P$. angustifolia $(1.5-3 \mathrm{~mm})$. The revision of specimens has shown that there are leaves 2-4 $\mathrm{mm}$ wide among those described by Doludenko as $P$. longifolia. In accordance with the width of leaves, the number of veins varies, while the number of veins per $5 \mathrm{~mm}$ of leaf blade width is constant. Thus, we have not revealed significant morphological differences between these two species.

The diagnosis of $P$. longifolia (Vakhrameev and Doludenko, 1961, pp. 115-116) indicates that stomata are arranged in bands. However, it is noted in the species description that stomata are distributed throughout the lower surface without forming bands and rows. Later, describing the leaf remains from the Irkutsk Basin under the same species name, Doludenko and Rasskazova (1972) noted the arrangement of stomata in bands. Having studied the epidermal structure of the type specimens of $P$. longifolia, we found that the stomata in the lower part of the leaves are arranged in bands. However, these bands are indistinct in some places, merging with each other (Plate II, fig. 6). According to Doludenko's descriptions, $P$. angustifolia differs from $P$. longifolia in the presence of the papillae on the subsidiary stomata cells. However, our data show that there are also rare papillae on the subsidiary cells of stomata of the leaves previously described as $P$. longifolia. On the basis of the similarity in the morphological and epidermal characters, the specimens described by Doludenko as $P$. longifolia are considered as $P$. angustifolia .

Krassilov (1972) included the species Pseudotorellia ensiformis described by Doludenko (Vakhrameev and Doludenko, 1961) in P. angustifolia, adding the following epidermal characters to the description: the presence of median cuticular thickenings (=ridges) on the periclinal cell walls on the upper leaf surface and the presence of papillae on the subsidiary cells of many stomata. Having studied P. ensiformis, we revealed a series of significant morphological and epidermal differences from $P$. angustifolia. Leaves of $P$. ensiformis differ markedly from $P$. angustifolia in their lanceolate shape, a larger width, and almost 10 -fold shorter length. Unlike $P$. angustifolia, cells of the upper epidermis in of $P$. ensiformis are differentiated into narrow, elongated cells located above the veins and wide cells, elongated and short, located between the veins. In addition, $P$. angustifolia differs from $P$. ensiformis in the absence of cuticular ridges on the epidermal cells. Our data confirm Doludenko's opinion that the Bureya lanceolate leaves should be considered as a certain species. Taking into account the fact that the epidermal structure of the type specimens of $P$. ensiformis from Ust'-Baley is unknown, we have distinguished a new species $P$. doludenkoae sp. nov. (see the description below).

According to the morphological and epidermal characters, Pseudotorellia angaranica (Kiritchkova et al., 2020) from the Irkutsk Basin is similar to $P$. angustifolia from the Bureya Basin. On the basis of these data, we consider this Irkutsk species as a junior synonym of $P$. angustifolia.

In general, Pseudotorellia angustifolia is characterized by narrow and long linear leaves, narrow elongated cells of both the upper and lower epidermis, the absence of cuticular thickenings and papillae on the ordinary epidermal cells, and the presence of rare small proximal papillae on some subsidiary cells of stomata.

Distribution. Dublikan Formation (Tithonian-Berriasian) of the Bureya Basin (Khabarovsk krai), Pereyaslovka (Lower Jurassic) and Kamala (Middle Jurassic) formations of the Kansk Basin (Eastern Siberia), Tyumen Formation (Bajocian) of the South Chasel field (Yamal-Nenets Autonomous Okrug), Naunan Formation (Callovian-Oxfordian) of the West Ostanino field (Tomsk oblast), and Prisayan Formation (Aalenian-Bajocian) of the Irkutsk Basin (Eastern Siberia).

M a terial. The right bank of the Bureya River, Kataevskaya channel, GIN RAS, spec. no. 3318/120-26 (more than 8 leaves and leaf fragments), spec. no. 3318/120-27 (5 leaf fragments); Chegdomyn settlement (mine no. 3), GIN RAS, spec. no. 3318/9-38 (more than 15 leaves and leaf fragments), Dublikan Formation (Tithonian-Berriasian).

Plate II. Pseudotorellia angustifolia Doludenko, Dublikan Formation, Tithonian-Berriasian. Scale bar for figs. 1-6, 8, 9-100 $\mu$ m; for figs. $7,10-50 \mu \mathrm{m}$; for figs. $11-13-20 \mu \mathrm{m}$. $(1,4,13)$ the right bank of the Bureya River, Kataevskaya channel, spec. no. 3318/120-27b (holotype): (1) stomata in the lower part of a leaf blade; (4) cells of the upper epidermis; (13) stoma; polar appendages of the guard cells and preserved inner walls of the guard cells are visible; $(2,3,5-12)$ Chegdomyn settlement (mine no. 3), spec. no. 3318/9-38: (2) resin duct; (3) upper (on the left) and lower (on the right) cuticles; (5) cells of the upper epidermis; (6) indistinct stomatal bands on the lower part of a leaf blade; (7) two stomata; (8) stomata and cells of the lower epidermis, SEM, internal view; (9) stomatal (three) and nonstomatal (two) bands; (10) two stomata, one of which with proximal papillae; (11) stoma with proximal papillae; (12) stoma, SEM, internal view. 


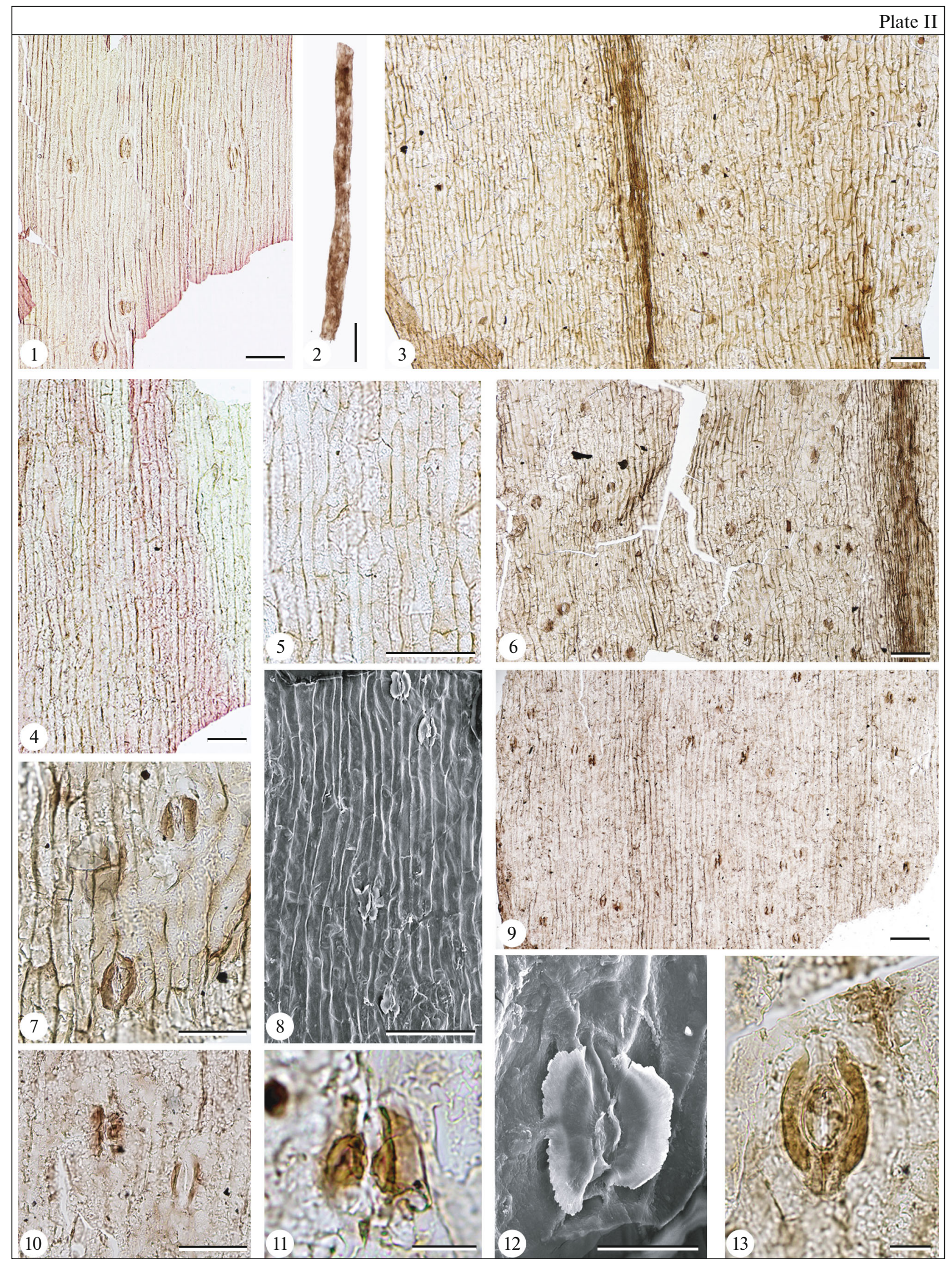

STRATIGRAPHY AND GEOLOGICAL CORRELATION Vol. 29 No. $4 \quad 2021$ 
Pseudotorellia crassifolia Doludenko, emend. Nosova, Kostina et Bugdaeva

Plate I, figs. 7, 9, 10; Plate III

Pseudotorellia crassifolia (Prynada) Doludenko: Vakhrameev and Doludenko, 1961, p. 114, Plate LVI, figs. 4, 5.

Pseudotorellia pulchella auct. non (Heer) Vassilevskaja, 1959: Vakhrameev and Doludenko, 1961, p. 113, Plate LVI, figs. 6, 7.

Holotype. GIN RAS, spec. no. 3318/58-3; Russian Far East, the right bank of the Bureya River, downstream of the Umalta River mouth; the upper subformaton of the Talyndzhan Formation, Oxfordian; Vakhrameev and Doludenko 1961, p. 113, Plate LVI, fig. 4; designated here, Plate I, fig. 7.

Emended diagnosis. Leaves oblanceolate, with their widest part at about the middle or slightly closer to the apex, apex rounded or obtuse; base cuneate. Leaves with $5-6$ veins per $5 \mathrm{~mm}$. Leaves hypostomatic. Cells of upper and lower epidermis tetra- to polygonal, elongate to short across intercostal zones and elongate across costal zone; periclinal cell walls smooth. Anticlinal epidermal cell walls of both leaf surfaces straight. Stomata assembled in bands. Stomatal complexes monocyclic, sometimes dicyclic. Subsidiary cells without papillae.

Description. Leaves are oblanceolate with obtuse or rounded apices (Plate I, figs. 7, 9, 10). Leaves are $30-45 \mathrm{~mm}$ long, $1-1.5 \mathrm{~mm}$ wide at the base, and 4-12 mm wide in the upper third. The number of veins in the wide part varies from 8 to 15 (5-6 veins per $5 \mathrm{~mm}$ of leaf blade width). There are resin ducts 28-60 $\mu \mathrm{m}$ wide between veins (Plate III, fig. 3). The maximum length of a resin duct is $2300 \mu \mathrm{m}$ (Plate III, fig. 8). Leaf cuticle is thin.

Leaves are hypostomatic. In terms of the shape of epidermal cells, costal (over the veins) and intercostal (between the veins) zones on the upper leaf surface are not always well defined and are roughly equal in width (Plate III, fig. 1). Zones over veins are formed by rows of tetra- and polygonal epidermal cells, wide (35$46 \times 93-115 \mu \mathrm{m})$ and narrow $(20-28 \times 100-167 \mu \mathrm{m})$. The epidermal cells are tetra- and polygonal (Plate III, fig. 2), short (30-89 × 45-92 $\mu \mathrm{m})$ and elongated (34$56 \times 70-114 \mu \mathrm{m})$ in the zones between the veins. The anticline walls of all upper epidermal cells are straight; the angles between them are sharp, less often rounded. The periclinal walls are smooth.

The lower epidermis consists of alternating nonstomatal and stomatal bands, corresponding to costal and intercostal zones (Plate III, fig. 4). The ordinary epidermal cells tetra- and polygonal, elongated $(20-45 \times$ $109-140 \mu \mathrm{m})$ in nonstomatal zones (Plate III, fig. 5), short $(37-41 \times 57-65 \mu \mathrm{m})$ and elongated $(25-37 \times$ 99-128 $\mu \mathrm{m})$ in stomatal bands. The anticlinal cell walls are straight smooth, with sharp angles between them, less often rounded. The periclinal walls are smooth. The stomata are arranged in bands very unevenly, oriented longitudinally. There are 3-4 (rarely up to 7) stomata per width of the band (Plate III, fig. 4). Stomatal complexes are monocyclic (Plate III, fig. 9), sometimes incompletely dicyclic (Plate III, fig. 10). There are 5-6 subsidiary cells of stomata; two of them are polar; there are no papillae on the subsidiary cells. The guard cells are sunken, wing-like (Plate III, figs. 7, 10). The guard cells are 26-47 $\mu \mathrm{m}$ long and 8-20 $\mu \mathrm{m}$ wide; polar appendages are not distinct. After the maceration, the outer walls, often the apertural and epidermal walls (Plate III, figs. 9, 11, 12), and rarely the inner walls of the guard cells (Plate III, fig. 12) are preserved.

Comparison and remarks. Doludenko described the combination $P$. crassifolia (Prynada) Doludenko, indicating V.D. Prynada in the synonymy as the author of the species name: "Feildenia crassifolia Prynada, Prynada, 1939 in Kheraskov et al.” (Vakhrameev and Doludenko, 1961, p. 114).

However, Kheraskov et al. (1939) presented only lists of species without descriptions and images. F. crassifolia was described by Prynada in an unpublished geological report (1937). This means that this species is invalid. Since Doludenko mistakenly indicated the type of this species as a neotype and gave a species diagnosis, the published taxon $P$. crassifolia (Vakhrameev and Doludenko, 1961) is valid. In the present paper, the specimen indicated by Doludenko as the neotype is accepted as the holotype.

The epidermal structure of the Bureya leaves described as $P$. pulchella has also been studied. It has been found that they are similar to $P$. crassifolia in all respects. Since the type material of $P$. crassifolia comes from the Bureya Basin, unlike $P$. pulchella, the Bureya leaves are described under the species name $P$. crassifolia. $P$. crassifolia differs significantly from $P$. angustifolia in its obovate lanceolate shape of leaves, 2-4 times wider and 2 times less long. Unlike $P$. crassifolia, the epidermal cells of both leaf surfaces surfaces of $P$. angustifolia are narrow and strongly elongated; the stomatal bands are narrower. Stomatal complexes are narrow and monocyclic, and the guard cells are larger.

D i s t r i b u t i o n. Upper subformation of the Talyndzhan Formation (Oxfordian), Bureya Basin (Khabarovsk krai).

Plate III. Pseudotorellia crassifolia Doludenko, the right bank of the Bureya River, downstream of the Umalta River mouth; the upper subformation of the Talyndzhan Formation, Oxfordian. Scale bar for figs. 1, 2, 4-6, 8-100 $\mu \mathrm{m}$; for fig. 3-1000 $\mu \mathrm{m}$; for figs. 7, 9-12-50 $\mu \mathrm{m}$. (1-6, 8-12) Spec. no. 3318/57-22: (1) cuticle of the upper leaf surface; (2) cells of the intercostal zone of the upper epidermis; (3) arrangement of resin ducts; (4) cuticle of the lower part of a leaf blade; (5) cells of the nonstomatal (costal) zone of the lower epidermis; (6) fragment of the stomatal band; (8) resin duct; (9-10) stomata; (11) stoma with preserved apertural and epidermal walls of the guard cells, SEM, internal view; (12) stomata; the preserved inner walls of the guard cells are visible on one of the stomata, SEM, internal view; (7) stomata on the lower part of a leaf blade, spec. no. 3318/58-3 (holotype). 


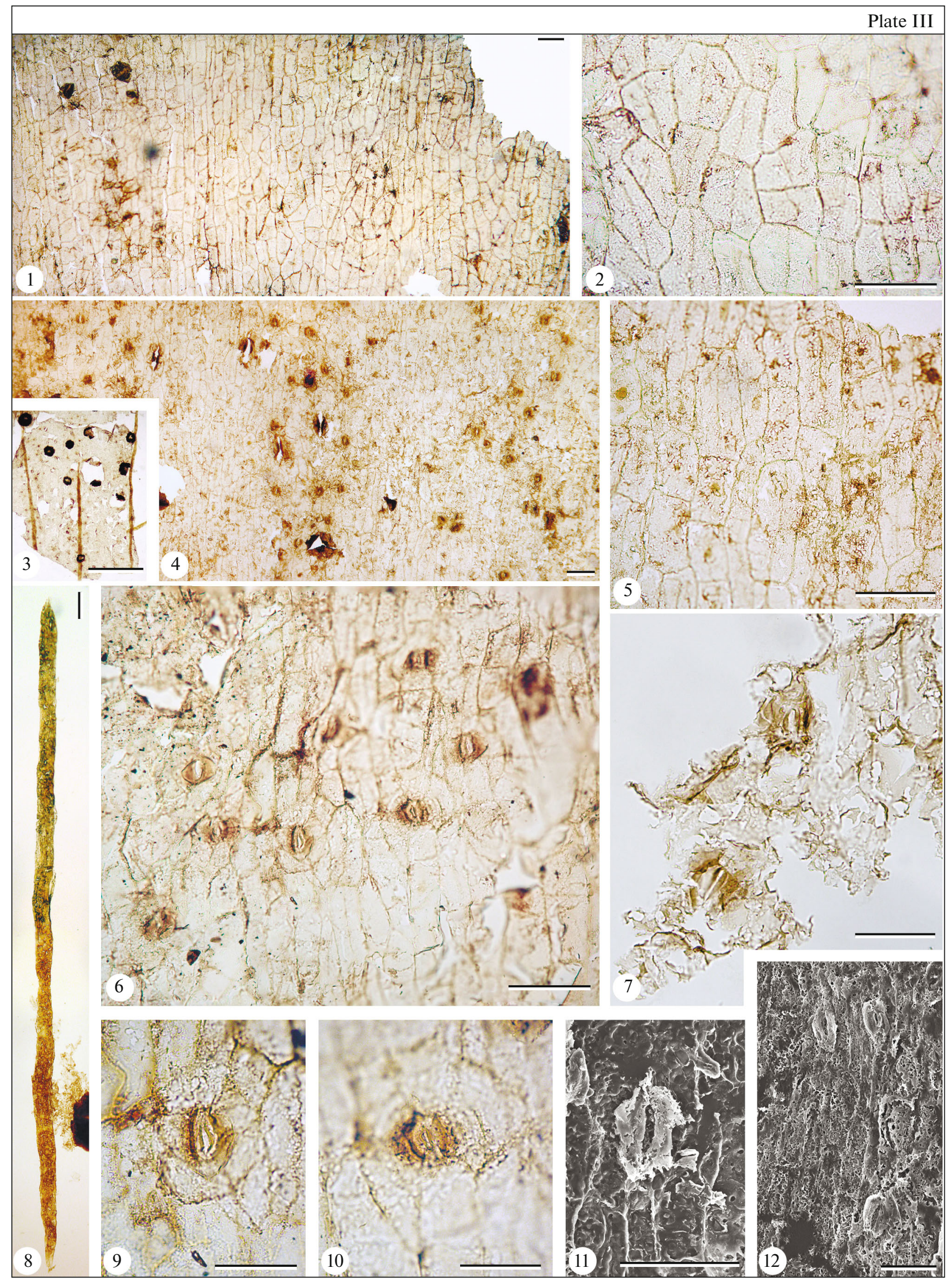


M a te rial. The right bank of the Bureya River, downstream of the Umalta River mouth; upper subformation of the Talyndzhan Formation, Oxfordian; GIN RAS, spec. no. 3318/58-3 (three fragments of leaves), spec. no. 3318/57-22 (more than 18 leaves and their fragments).

\section{Pseudotorellia doludenkoae Nosova, Kostina et Bugdaeva, sp. nov.}

Plate I, figs. 5, 6, 8; Plates IV, V

Pseudotorellia ensiformis (Heer) Doludenko: Vakhrameev and Doludenko, 1961, p. 111, Plate LV, figs. 1-8; Plate LVI, figs. 1-3.

Pseudotorellia angustifolia Doludenko: Krassilov, 1972, p. 58, pro parte, Plate XXI, figs. 3, 5 .

Ethymology. In honor of paleobotanist M.P. Doludenko.

H o l o t y p e. FSC EATB FEB RAS, no. 515/284a, Russian Far East, the right bank of the Bureya River, downstream of the Umalta River mouth; the upper subformation of the Talyndzhan Formation, Oxfordian; Krassilov, 1972, Plate XXI, fig. 5; designated here, Plate I, figs. 5a, 6.

Diagnosis. Leaves oblanceolate, with their widest part at about the middle or slightly closer to the apex. Leaf apex rounded or obtuse; base cuneate. Leaves with 5-6 veins per $5 \mathrm{~mm}$ in the widest part. Leaves hypostomatic. Cells of upper and lower epidermis tetra-, rarely pentagonal; elongate to short across intercostal zones and elongate across costal zones. Some cells of the upper epidermis and most cells of the lower epidermis with longitudinal cuticular ridges; anticlinal cell walls of both leaf surfaces straight. Stomata assembled in narrow bands. Subsidiary cells without papillae, very rarely with small papillae.

Description. Leaves the oblanceolate, with obtuse or rounded apices (Plate I, figs. 5, 6, 8). Leaves the 38-65 mm long, $1-2 \mathrm{~mm}$ wide at the base and 6$13 \mathrm{~mm}$ wide in the upper third. There are $8-10$ veins in the middle part of a leaf (5-6 veins per 5-mm-wide leaf plate). Resin ducts, 59-80 $\mu \mathrm{m}$ wide, are located between veins (Plate V, figs. 6, 11).

Leaves are hypostomatic. The upper epidermis is composed of tetra- and pentagonal cells, short $(30-50 \times$ $36-115 \mu \mathrm{m})$ and narrow elongated $(18-30 \times 110-$ $170 \mu \mathrm{m}$ ), located predominantly over veins (Plate IV, figs. 2, 4, 5; Plate V, fig. 7). Corners of the epidermal cells the rounded, rarely acute; anticlinal walls smooth. Cells of the upper epidermis near leaf edges have cuticular ridges (Plate V, fig. 1); other epidermal cells of the upper leaf surface have smooth periclinal walls (Plate IV, figs. 2, 4, 5).

The lower epidermis consists of alternating stomatal (130-310 $\mu \mathrm{m}$ wide) and nonstomatal (215-400 $\mu \mathrm{m}$ wide) bands (Plate IV, figs. 1, 3, 6; Plate V, figs. 3, 11). Cells of the nonstomatal bands are tetra- and pentagonal, narrow elongated $(10-30 \times 110-195 \mu \mathrm{m})$; cells of the stomatal bands are both elongated and short $(30-55 \times 40-156 \mu \mathrm{m})$; the anticlinal walls are smooth. Most cells have a longitudinal cuticular ridge, which is sometimes traced from one cell to another (Plate IV, fig. 6; Plate V, figs. 1, 5). The ridges are narrow (Plate IV, figs. 3, 7; Plate V, fig. 1) to wide (Plate IV, figs. 1, 6; Plate V, fig. 5), each of them is located in the central part of a cell (Plate IV, figs. 3, 7, 8; Plate. V, figs. 1, 4) or shifted toward one of the longitudinal anticlinal walls (Plate IV, fig. 6; Plate V, fig. 5). The number of stomata in a stomatal band varies from 2 to 5 (Plate IV, figs. 1, 3, 6; Plate V, figs. 1, 3, 11). The stomata in the stomatal bands are not arranged into distinct rows and are orientated longitudinally. Stomatal complexes are monocyclic, rarely incompletely dicyclic. Most of the stomatal complexes lack any papillae on the subsidiary cells (Plate IV, figs. 3, 8; Plate V, figs. $1,4,5,10)$; rarely subsidiary cells have small proximal papillae (Plate IV, figs. 1, 6; Plate V, fig. 2). In the polar parts of stomata, appendages are swallowtailed or T-shaped (Plate IV, fig. 8; Plate V, fig. 2). Stomata with these appendages are 65-90 $\mu \mathrm{m}$ long; the guard cells without appendages are 38-63 $\mu \mathrm{m}$ long, $10-18 \mu \mathrm{m}$ wide. After the maceration, the outer walls and sometimes inner walls of the guard cells are preserved (Plate IV, fig. 8; Plate V, figs. 5, 8, 9).

Comparison and remarks. The combination Pseudotorellia ensiformis was proposed by Doludenko on the basis of the similarity of morphological characters of leaves from the Bureya Basin and Podozamites ensiformis described by Heer (1876) from the Jurassic of the Ust'-Baley locality in the Irkutsk Basin (Heer, 1876). However, in contrast to leaves from the Irkutsk Basin, the epidermal structure of the Bureya leaves was studied (Vakhrameev and Doludenko, 1961). Later, Doludenko and Rasskazova noted that the identification of the specimens of Pseudotorellia ensiformis from the Bureya Basin with the material from the Irkutsk Basin was incorrect since the epidermal characters of the Irkutsk leaves are unknown (Doludenko and Rasskazova, 1972, p. 21) and proposed to attribute to this species leaves with unknown epidermal features and the same morphological characters as

Plate IV. Pseudotorellia doludenkoae Nosova, Kostina et Bugdaeva, sp. nov. Scale bar for figs. 1-7-100 $\mu \mathrm{m}$; for fig. $8-50 \mu \mathrm{m}$. $(1-3,6)$ The right bank of the Bureya River, downstream of the Umalta River mouth; the upper subformation of the Talyndzhan Formation, Oxfordian: $(1,6)$ fragments of the lower epidermis, spec. no. 515/284a (holotype); (2) fragment of the upper epidermis, spec. no. 515/284a (holotype); (3) stomatal and nonstomatal bands of the lower epidermis, spec. no. 515/272; $(4,5,7,8)$ the right bank of the Bureya River, Kataevskaya channel; Dublikan Formation, Tithonian-Berriasian: $(4,5)$ epidermal cells of the upper epidermis: (4) spec. no. 3318/54-90; (5) spec. no. 3318/52-4; (7) cells of the nonstomatal band, spec. no. 3318/120-28; (8) stoma, spec. no. 3318/52-4. 


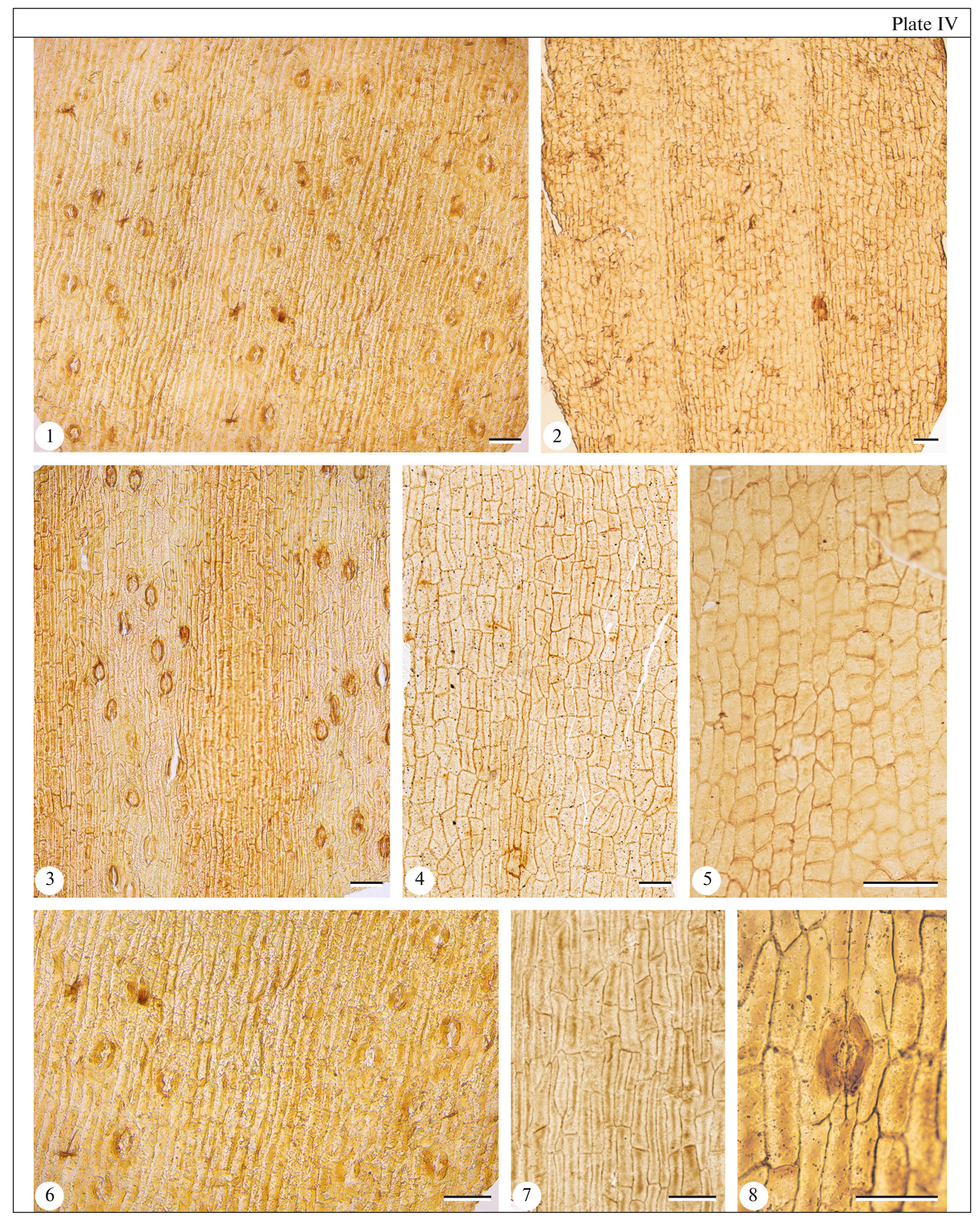




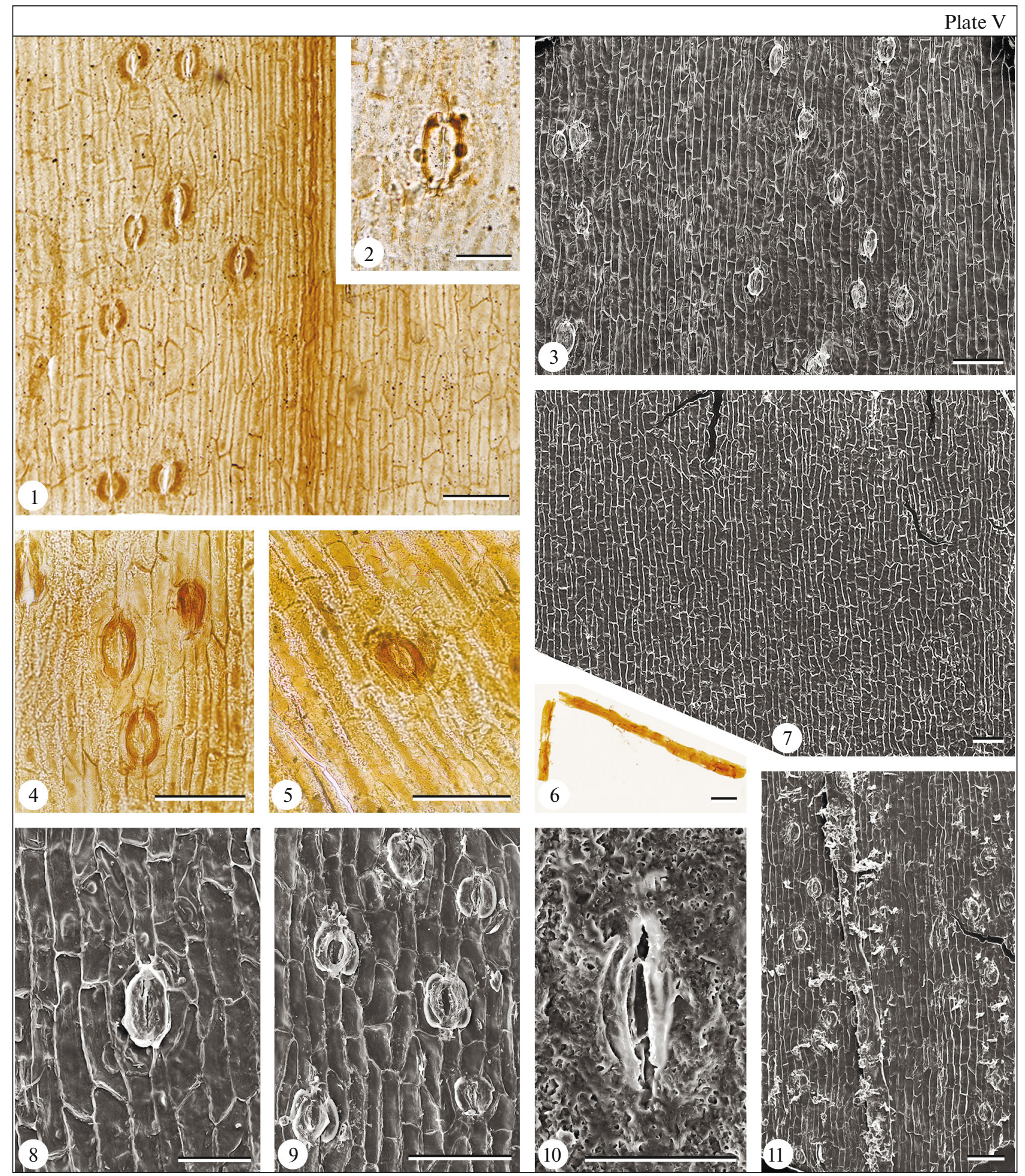

Plate V. Pseudotorellia doludenkoae Nosova, Kostina et Bugdaeva, sp. nov. Scale bar for figs. 1, 3-7, 9, 11-100 $\mu \mathrm{m}$; for figs. 2, 8, $10-50 \mu \mathrm{m} .(1,2)$ The right bank of the Bureya River, Kataevskaya channel; Dublikan Formation, Tithonian-Berriasian: (1) a marginal stomatal band of the lower epidermis (on the left) and cells of the upper epidermis (on the right), spec. no. 3318/57-6; (2) stomata, spec. no. 3318/118; (3-11) the right bank of the Bureya River, downstream of the Umalta River mouth; the upper subformation of the Talyndzhan Formation, Oxfordian: (3) stomatal and nonstomatal bands, SEM, internal view, spec. no. 515/272; (4) stomata, spec. no. 515/272; (5) stoma, spec. no. 515/284a (holotype); (6) resin duct, spec. no. 515/284a (holotype); (7) cells of the upper epidermis, SEM, internal view, spec. no. 515/272; (8) stoma with preserved inner walls of the guard cells, SEM, internal view, spec. no. 515/272; (9) stomata, SEM, internal view, spec. no. 515/284a (holotype); (10) stoma, SEM, external view, spec. no. 515/284a (holotype); (11) stomatal bands and resin duct, SEM, internal view, spec. no. 515/284a (holotype). 
the chosen lectotype from Ust'-Baley. Because of this, we consider leaves from the Bureya Basin described by Doludenko as $P$. ensiformis as a new species.

The leaves of $P$. doludenkoae are similar to P. crassifolia in the morphology (see description above) but they differ considerably in the epidermal characters. The leaf cuticles of the new species are notably thicker than $P$. crassifolia cuticles. In addition, $P$. doludenkoae differs considerably from $P$. crassifolia in the presence of cuticular ridges on periclinal walls of the epidermal cells and larger stomata.

P. doludenkoae differs from P. angustifolia in the lanceolate shape of leaves, which are wider and shorter. Unlike $P$. angustifolia, the upper epidermis cells of $P$. doludenkoae are differentiated in shape into narrow elongated cells located over veins and wide elongated and short cells located between bands of narrow cells. Moreover, the new species differs from $P$. angustifolia in the presence of cuticular ridges on epidermal cells.

On the basis of the morphology and dimensions of leaves, the arrangement of stomata in bands, the presence of cuticular ridges on the main epidermal cells, and the absence of papillae on the subsidiary cells in most stomata, $P$. doludenkoae is similar to $P$. grojecensis Reymanówna from the Lower Jurassic of Poland (Reymanówna, 1963), P. krassilovii Bugdaeva from the Lower Cretaceous of Southern Primorye (Bugdaeva and Markevich, 2009), and P. retusa Bose et Manum from the Lower Cretaceous of Spitsbergen (Bose and Manum, 1990; Pott et al., 2016).

P. grojecensis differs from $P$. doludenkoae in a peculiar structure of the upper epidermis consisting of "units" of tetragonal cells of the same length, oriented either along or across the leaf axis.

In contrast to the new species, cuticular thickenings on the periclinal walls of the ordinary epidermal cells in $P$. krassilovii are formed by accumulations of small flattened papillae. In addition, stomatal bands in $P$. krassilovii are three times wider than nonstomatal ones, while nonstomatal bands in P. doludenkoae are equal to or somewhat wider than stomatal bands.

$P$. retusa differs from $P$. doludenkoae in smaller dimensions of leaves $(3-5 \times 10-19 \mathrm{~mm})$, dentate leaf margin, wider stomatal bands (up to 6 stomata per band width), and weakly curved anticlinal walls of some epidermal cells.

Distribution. Upper subformation of the Talyndzhan Formation (Oxfordian) and the Dublikan Formation (Tithonian-Berriasian) of the Bureya Basin (Khabarovsk krai).

Material. The right bank of the Bureya River, downstream of the Umalta River mouth; the upper subformation of the Talyndzhan Formation, Oxfordian; FSC EATB FEB RAS, spec. no. 515/272 (more than ten leaves and their fragments), spec. no. 515/284 (four leaves); GIN RAS, spec. nos. 3318/52-3, 3318/52-4, and 3318/54-9; Kataevskaya channel; Dub- likan Formation, Tithonian-Berriasian; GIN RAS, spec. nos. 3318/118-1, 3318/118-2, and 3318/120-25.

\section{CONCLUSIONS}

Detached leaves of Pseudotorellia and their fragments have similar morphology with some leaves of Phoenicopsis Heer, Eretmophyllum Thomas, and Podozamites Braun, as well as with leaf fragments of Baiera Braun and Sphenobaiera Florin. Therefore, their determination should be based not only on morphology but also on the epidermal structure. The epidermal characters of Pseudotorellia leaves make it possible to recognize this genus quite clearly from other fossil taxa. In addition, they are also important for identifying new species, since the Pseudotorellia leaves that are similar in morphology often have different structures of the epidermis. This is also confirmed by our studies of the Pseudotorellia leaf remains from the Bureya Basin, where the leaves of $P$. crassifolia and P. doludenkoae sp. nov., similar in shape and size, have completely different epidermal structures. The cuticle of most Pseudotorellia leaves is quite thick, resistant to chemical maceration. This allows us to study in detail their epidermal structure and determine the systematic belonging of whole leaves and their fragments, as well as dispersed cuticles. This indicates the stratigraphic significance of the genus Pseudotorellia, especially in the case of studying borehole material and coal specimens, where the preservation of plant remains does not allow us to identify confidently their morphology.

The taxonomic composition of the genus Pseudotorellia and the stratigraphic and geographical belonging of the species were repeatedly refined by different authors (Bugdaeva, 1999; Horiuchi and Uemura, 2017; Kiritchkova and Nosova, 2009; Nosova and Golovneva, 2018). As a result of our revision based on morphological and epidermal characters, the number of Pseudotorellia species from the Bureya Basin comes down to three species (Table 1).

Remains of Pseudotorellia angustifolia leaves were found in the Dublikan Formation, remains of P. crassifolia leaves were found in the Talyndzhan Formation, and $P$. doludenkoae sp. nov. leaves were found both in the Talyndzhan Formation and in the Dublikan Formation. In the future, these species can be used as correlative taxa for the intrabasin and interregional correlation of continental strata.

We have revised all known leaf remains previously described as Pseudotorellia angustifolia, and included in the composition of this species only leaves having the epidermal characters similar to those of type specimens from the Bureya Basin. On the basis of the data obtained, we conclude that $P$. angustifolia had a noticeably broad distribution in the Jurassic and Early Cretaceous of Siberia and the Russian Far East. In addition to the Tithonian-Berriasian of the Bureya 
Table 1. The results of revision of the taxonomic composition of the genus Pseudotorellia from the Bureya Basin

\begin{tabular}{|c|c|c|}
\hline Vakhrameev and Doludenko, 1961 & Krassilov, 1972 & $\begin{array}{l}\text { Results of revision } \\
\text { (this paper) }\end{array}$ \\
\hline P. angustifolia Doludenko & P. angustifolia Doludenko & \multirow{2}{*}{ P. angustifolia Doludenko } \\
\hline P. longifolia Doludenko & P. longifolia Doludenko & \\
\hline P. pulchella (Heer) Vassilevskaja & \multirow{2}{*}{ P. (Eretmophyllum?) pulchella (Heer) Vassilevskaja } & \multirow{2}{*}{ P. crassifolia Doludenko } \\
\hline P. crassifolia (Prynada) Doludenko & & \\
\hline P. ensiformis (Heer) Doludenko & P. angustifolia Doludenko & P. doludenkoae sp. nov. \\
\hline
\end{tabular}

Basin, this species is known from the Lower and Middle Jurassic of the Kansk Basin (Kostina, 2004), from the Middle Jurassic of the Yamal-Nenets Autonomous Okrug, from the Middle and Upper Jurassic of Tomsk oblast (Kiritchkova et al., 2005), and from the Middle Jurassic of the Irkutsk Basin (Kiritchkova et al., 2020). Apparently, $P$. angustifolia originated in the Early Jurassic on the modern territory of Eastern Siberia (Kansk Basin). In the Middle Jurassic, its habitat area expanded both to the northwest (Tomsk oblast and the Yamal-Nenets Autonomous Okrug), where this species was locally preserved (Tomsk oblast) until the Late Jurassic, and to the east, up to the Irkutsk oblast and Khabarovsk krai (Bureya Basin), where it survived to the Early Cretaceous (Berriasian). Perhaps, this evolutionary stasis of $P$. angustifolia was caused by the existence of the plant under the same warm and humid paleoclimatic conditions within these territories.

\section{ACKNOWLEDGMENTS}

We are grateful to A.B. Doweld (National Institute of Carpology (Gaertnerian Institution), Moscow) for advice in solving synonymy issues and M.A. Afonin (FSC EATB FEB RAS, Vladivostok) for assistance in searching the literature.

\section{FUNDING}

This work was supported by the Russian Foundation for Basic Research (project no. 20-04-00355) and within the State Assignments of BIN RAS (project no. AAAA-A19119021190031-8), GIN RAS (project no. 0135-2019-0045), and FSC EATB FEB RAS (project no. AAAA-A17117062710083-0).

This work was conducted using equipment of the Core Facility Center "Cell and Molecular Technologies in Plant Science" at the BIN RAS. (St. Petersburg) and the Center for Shared Access of FSC EATB FEB RAS (Vladivostok).

Reviewers E.B. Volynets and A.B. Herman

\section{OPEN ACCESS}

This article is licensed under a Creative Commons Attribution 4.0 International License, which permits use, sharing, adaptation, distribution and reproduction in any medium or format, as long as you give appropriate credit to the original author(s) and the source, provide a link to the Creative Commons license, and indicate if changes were made. The images or other third party material in this article are included in the article's Creative Commons license, unless indicated other- wise in a credit line to the material. If material is not included in the article's Creative Commons license and your intended use is not permitted by statutory regulation or exceeds the permitted use, you will need to obtain permission directly from the copyright holder. To view a copy of this license, visit http://creativecommons.org/licenses/by/4.0/.

\section{REFERENCES}

Anoikin, V.I., Gosudarstvennaya geologicheskaya karta Rossiiskoi Federatsii. Masshtab 1: 200000 (Izd. 2-oe). Seriya Bureinskaya. List M-53-VIII (Chegdomyn). Ob'yasnitelnaya Zapiska (The 1: 200000 State Geological Map of the Russian Federation (2nd ed.). Bureya Ser., Sheet M-53-VIII (Chegdomyn). Explanatory Note), St. Petersburg: Kart. Fabr. Vseross. Nauchno-Issled. Geol. Inst., 2003 [in Russian].

Bose, M.N. and Manum, S.B., Mesozoic conifer leaves with "Sciadopitys-like" stomatal distribution. A re-evaluation based on fossils from Spitsbergen, Greenland and Baffin Island, Norsk Polarinst. Skr., 1990, vol. 192, pp. 1-81.

Bugdaeva, E.V., The history of the genus Pseudotorellia Florin (Pseudotorelliaceae, Ginkgoales), Paleontol. J., 1999, vol. 33, no. 5, pp. 566-576.

Bugdaeva, E.V. and Markevich, V.S., The coal-forming plants of Rhabdopissites in the Lipovtsy Coal Field (Lower Cretaceous of Southern Primorye), Paleontol. J., 2009, vol. 43, no. 10, pp. 1217-1229.

Chen, F., Meng, X.Y., Ren, S.Q., and Wu, C.L., The Early Cretaceous Flora of Fuxin Basin and Tiefa Basin, Liaoning Province, Beijing: Geol. Publ. House, 1988 [in Chinese].

Davydova, T.P. and Gol'dshtein, Ts.L., Litologicheskie issledovaniya $v$ Bureinskom basseine (Lithological Studies in the Bureya Basin), Moscow: Gosgeolizdat, 1949 [in Russian].

Doludenko, M.P. and Rasskazova, E.S., Ginkgoales and Czekanowskiales of the Irkutsk Basin, in Mezozoiskie rasteniya (ginkgovye i chekanovskievye) Vostochnoi Sibiri ((Mesozoic Plants (Ginkgoales and Czekanowskiales) of Eastern Siberia), Moscow: Nauka, 1972, pp. 7-43.

Dong, C., Zhou, Z., Zhang, B., Wang, Y., and Shi, G., Umaltolepis and associated Pseudotorellia leaves from the Middle Jurassic of Yima in Henan Province, Central China, Rev. Palaeobot. Palynol., 2019, vol. 271, pp. 104-111.

Florin, R., Die fossilen Ginkgophyten von Franz-JosephLand nebst Erorterung uber vermeintliche Cordaitales mesozoischen Alters. I. Spezieller Teil, Palaeontogr. Abt. B, 1936, vol. 81, pp. 71-173.

Golovneva, L.B. and Nosova, N.V., Al'b-senomanskaya flora Zapadnoi Sibiri (Albian-Senomanian Flora of Western Siberia), St. Petersburg: Marafon, 2012 [in Russian].

Gordenko, N.V., Vladimariales ordo nov. (Gymnospermae) from the Middle Jurassic (Kursk Region, European Russia), Paleontol. J., 2010, vol. 44, no. 10, pp. 1281-1307.

Gosudarstvennaya geologicheskaya karta Rossiiskoi Federatsii. Masshtab 1:1000000 (tret'e pokolenie). Seriya Dal'nev- 
ostochnaya. List M-53 - Khabarovsk. Ob"yasnitel'naya zapiska (The 1: 1000000 State Geological Map of the Russian Federation (3rd ed.). Far Eastern Ser., Sheet M-53 (Khabarovsk). Explanatory Note), St. Petersburg: Kart. Fabr. Vseross. Nauchno-Issled. Geol. Inst., 2009 [in Russian].

Heer, O., Beiträge zur Jura-Flora Ostsibiriens und des Amurlandes, Bull. Acad. Imp. Sci. St.-Petersbourg, 1876, Ser. VII, vol. XXII, no. 12, Flora Fossilis Arctica: Die Fossile Flora der Polarländer, vol. 4, Zürich: Verlag, 1877.

Heer, O., Beiträge zur fossilen Flora Sibiriens und des Amurlandes, Mém. Acad. Imp. Sci. St.-Pétesbourg. Sér. 7, Vol. 25, No. 6, Flora Fossilis Arctica: Die Fossile Flora der Polarländer, vol. 5, St. Petersbourg: Acad. Imp. Sci., 1878b. Herrera, F., Shi, G., Ichinnorov, N., Takahashi, M., Bugdaeva, E.V., Herendeen, P.S., and Crane, P.R., The presumed ginkgophyte Umaltolepis has seed-bearing structures resembling those of Peltaspermales and Umkomasiales, Proc. Nat. Acad. Sci. U.S.A., 2017, vol. 114, pp. E2385-E2391.

Horiuchi, J. and Uemura, K., Paleocene occurrence of Pseudotorellia Florin (Ginkgoales) from Northeast Japan and the Meso-Cenozoic history of Pseudotorellia and Torellia, Rev. Palaeobot. Palynol., 2017, vol. 246, pp. 146-160. Kheraskov, N.P., Davydova, T.N., Krasheninnikov, G.F., and Peninskii, D.D., Geology of the Bureya Basin, in Tr. Vsesoyuz. Nauchno.-Issled. Inst. Mineral. Syr'ya, Vyp. 149 (Proc. All-Union Sci.-Res. Inst. Miner. Resour. Vol. 149), Moscow: GONTI, 1939.

Kiritchkova, A.I. and Nosova, N.V., The genus Pseudotorellia Florin (Ginkgoales): Taxonomic and stratigraphic aspects, Stratigr. Geol. Correl., 2009, vol. 17, no. 6, pp. 615-631. Kiritchkova, A.I., Kostina, E.I., and Bystritskaya, L.I. Fitostratigrafiya i flora yurskikh otlozhenii Zapadnoi Sibiri (Phytostratigraphy and Flora of the Jurassic Sediments of Western Siberia), St. Petersburg: Nedra, 2005 [in Russian].

Kiritchkova, A.I., Nosova, N.V., Kostina, E.I., and Yaroshenko, O.P., Kontinental'naya yura Irkutskogo uglenosnogo basseina (Jurassic Continental Deposits of the Irkutsk Coal Basin), St. Petersburg: Vseross. Nauchno-Issled. Geol. Inst., 2020 [in Russian].

Kostina, E.I., Yurskaya flora Kanskogo uglenosnogo basseina (Jurassic Flora of the Kansk Coal-Bearing Basin), Moscow: GEOS, 2004 [in Russian].

Krassilov, V.A., Mezozoiskaya flora reki Burei (Ginkgoales $i$ Czekanowskiales) (Mesozoic Flora of the Bureya River (Ginkgoales and Czekanowskiales)), Moscow: Nauka, 1972 [in Russian].

Krassilov, V.A., Materials on the stratigraphy and paleofloristics of the coal-bearing stratum of the Bureya basin, in Iskopaemye flory i fitostratigrafiya Dal'nego Vostoka (Fossil Floras and Phytostratigraphy of the Far East), Vladivostok: Dalnevost. Nauchn. Tsentr Akad. Nauk SSSR, 1973, pp. 28-51.

Lebedev, E.L. and Paraketsov, K.V., About the Jurassic-Cretaceous boundary in the continental deposits of the Far East, Izv. Akad. Nauk SSSR. Ser. Geol., 1975, no. 4, pp. 124-133.

Markevich, V.S., Melovaya palinoflora severa Vostochnoi Azii (Cretaceous Palynoflora of Northeastern Asia), Vladivostok: Dal'nauka, 1995 [in Russian].

Markevich, V.S. and Bugdaeva, E.V., Palynological evidence for dating Jurassic-Cretaceous boundary sediments in the Bureya basin, Russian Far East, Russ. J. Pac. Geol., 2009, vol. 28, no. 3, pp. 284-293.

Markevich, V.S. and Bugdaeva, E.V., Late Jurassic-Early Cretaceous coal-forming plants of the Bureya Basin, Russian Far East, Stratigr. Geol. Correl., 2014, vol. 22, no. 3, pp. 239-255.

Nosova, N., Female reproductive structures of Umaltolepis Krassilov and associated short shoots, buds and leaves of
Pseudotorellia Florin from the Middle Jurassic of Angren, Uzbekistan, Rev. Palaeobot. Palynol., 2020, vol. 281.

https://doi.org/10.1016/j.revpalbo.2020.104266

Nosova, N. and Golovneva, L., Phoenicopsis (Leptostrobales) and Pseudotorellia (Ginkgoales) from the Cretaceous of North Asia, Cretaceous Res., 2018, vol. 86, pp. 149-162.

Petruk, N.N., Volkova, Yu.R., Shilova, M.N., et al., Gosudarstvennaya geologicheskaya karta Rossiiskoi Federatsii, masshtab 1: 1000000 (tret'e pokolenie). Seriya Dal'nevostochnaya. List M-52 - Blagoveshchensk. Ob"yasnitel'naya zapiska (The 1: 1000000 State Geological Map of the Russian Federation (3rd ed.). Far Eastern Ser., Sheet M-52 (Blagoveshchensk). Explanatory Note), St. Petersburg: Vseross. Nauchno-Issled. Geol. Inst., 2012 [in Russian].

Pott, C., Van der Burgh, J., and Van Konijnenburg-van Cittert, J.H.A., New ginkgophytes from the Upper TriassicLower Cretaceous of Spitsbergen and Edgeøya (Svalbard, Arctic Norway): The history of Ginkgoales on Svalbard, Int. J. Plant Sci., 2016, vol. 177, pp. 175-197.

Resheniya IV Mezhvedomstvennogo regional'nogo stratigraficheskogo soveshchaniya po dokembriyu i fanerozoyu yuga Dal'nego Vostoka i Vostochnogo Zabaikal'ya (Khabarovsk, 1990). Ob"yasnitel'naya zapiska k stratigraficheskim skhemam (Resolutions of the IV Interdepartmental Regional Stratigraphic Conference on the Precambrian and Phanerozoic in the Far East and Eastern Transbaikalia (Khabarovsk, 1990). Explanatory Note to Stratigraphic Schemes), Khabarovsk: KhGGGP, 1994. 124 s.

Reymanówna, M., The Jurassic flora from Grojec near Cracow in Poland, Pt. 1, Acta Palaeobot., 1963, vol. 4, pp. 9-48. Schweitzer, H.J. and Kirchner, M., Die Rhäto-Jurassischen Floren des Iran und Afghanistans. 8. Ginkgophyta, Palaeontographica, 1995, vol. 237, pp. 1-58.

Shi, G., Crane, P.R., Herendeen, P.S., Ichinnorov, N., Takahashi, M., and Herrera, F., Diversity and homologies of corystosperm seed-bearing structures from the Early Cretaceous of Mongolia, J. Systematic Palaeontol., 2019, vol. 17, no. 12, pp. 997-1029.

Stanislavsky, F.A., The new genus Toretzia from the Upper Triassic of the Donetsk Basin and its relation to the genera of the order Ginkgoales, Paleontol. Zh., 1973, vol. 1, pp. 88-96. Vasilevskaya, N.D., Gymnosperm plants from coal-bearing deposits of the Sangar District (Lena Coal Basin), in $S b$. Statei po Paleontologii i Biostratigrafii (Coll. Sci. Works on Paleontology and Biostratigraphy), Leningrad: NaucnoIssled. Inst. Arktiki, 1959. pp. 49-76.

Vakhrameev, V.A. and Doludenko, M.P., Late Jurassic and Early Cretaceous flora of the Bureya Basin and its significance for stratigraphy, in $T r$. GIN $A N$ SSSR (Trans. Geol. Inst. USSR Acad. Sci.), 1961, vol. 54.

Vakhrameev, V.A. and Lebedev, E.L., Paleobotanic characteristic and age of the Upper Mesozoic coal-bearing deposits of the Russian Far East (the Amur-Uda Interfluve), Izv. Akad. Nauk SSSR. Ser. Geol., 1967, no. 2, pp. 120-133.

Wang, Z.Q., Plant kingdom, in Palaeontological Atlas of North China, II. Mesozoic, Tianjin Inst. Geol. Miner. Resour., Geol. Publ. House, Beijing, 1984, pp. 223-296 (in Chinese).

Watson, J., A revision of the English wealden flora I: Charales-Ginkgoales, Bull. Br. Mus. Nat. Hist. (Geol.), 1969, vol. 17, no. 5, pp. 209-254.

Zhou, Z.Y., Phylogeny and evolutionary trends of Mesozoic ginkgoaleans: A preliminary assessment, Rev. Palaeobot. Palynol., 1991, vol. 68, pp. 203-216.

Translated by D. Voroshchuk 